\title{
Music beyond Medicine - Perspectives of Chinese Pianist
}

\author{
Interview with Kong Xiangdong \\ 超越药物的音乐 : 中国钢琴家的视角 \\ 特色艺术家 - 采访孔祥东
}

Tony Yu Zhou

Inspirees Institute, China

\begin{abstract}
Xiang-Dong Kong (born 1968, in Shanghai), Chinese pianist, one of the musicians featured in the 1979 documentary film, From Mao to Mozart: Isaac Stern in China. Kong was the Gold Medalist at the 1988 Gina Bachauer International Piano Competition. In 1992 he won the Sydney International Piano Competition. Dr. Tony Zhou, the executive editor of CAET, interviewed Kong for the Featured Artist column of the journal. The pianist shared his story and mission to bring music to the public to improve the well-being of humanity. This text is edited from the original video interview done July 16, 2019 (see video 1).
\end{abstract}

Keywords: Piano, Xiang-Dong Kong, China, Music Education

\section{摘要}

孔祥东，中国著名钢琴演奏家，曾多次在国际钢琴比赛中荣获金奖，2008年北 京奥运会主题曲之一“永远的朋友” 主创作曲家。在CAET执行主编周宇博士对 他的采访中，他分享了自己从音乐家走向教育家的心路历程，并致力于将音乐 带给大众并提升人类健康和幸福的故事。本文是在原采访视频上编辑完成的。

关键词 : 钢琴，孔祥东，中国，音乐教育

TZ: Could you please introduce yourself a bit?

KXD: My name is Xiangdong Kong, the $75^{\text {th }}$ descendant of the Chinese philosopher Confucius. I began practicing the piano on a paper keyboard drawn by my mother, my first mentor. I started learning piano at seven from her on this paper piano. It was years before I actually touched a real instrument. The training in my early childhood helped me to develop my inside feelings for the piano and enrich my musicality for music creation and performance. Later, I entered the Shanghai Conservatory of Music at the age of 9. When I was sixteen, I won the first prize at the national competition of piano. At seventeen, I entered the Tchaikovsky competition in Russia,

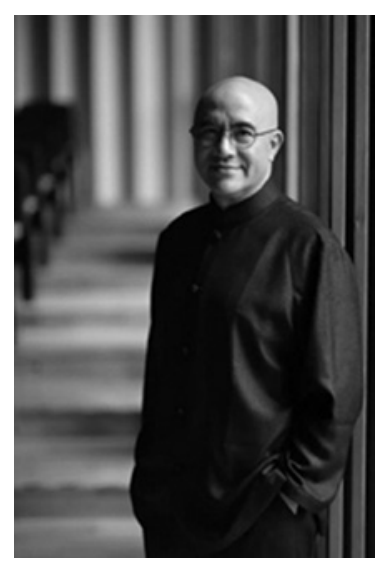


and afterwards, I won various international awards in Spain, the USA, and Australia. I came back to China in 1997 after I spent a few years of study at The Curtis Institute of Music in Philadelphia, USA. I established my own organization, the Kong Xiangdong Music Education Center in China. For 17 years, I dedicated myself to music education and have built up music kindergartens, music colleges and music centers in seven cities in China. I also collaborated with some renowned Hollywood composers and Hong Kong pop-stars. For instance, I composed the song "Love You Ten Thousand Years" for Andy Lau, and created the song, "Forever

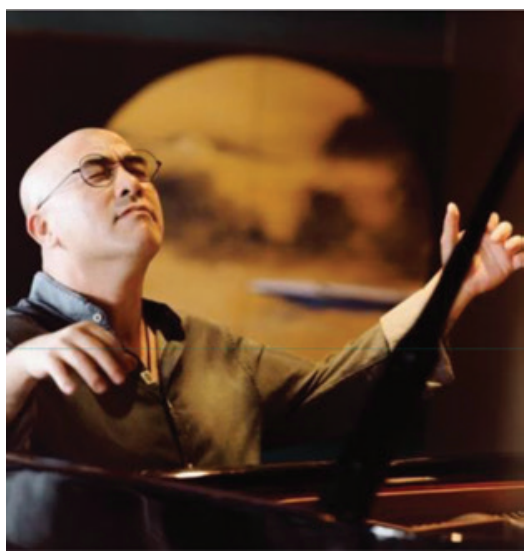
Friends" with Giorgio Moroder for the 2008 Beijing Olympics. All my works cover music education, creation, and performance, as well as organization in this field.

TZ: Looking back, what are the most important milestones in your life? What impact has art/music had during these milestones?

KXD: I must say, the most important milestone was learning music in my early childhood, which was a very difficult time to find a piano to play. My mother was a great mentor and enabled me to get contact with music and also made me love music. That totally changed my life. Without music, I have no idea where I would be today. After studying and spending so many years on music in the US, I came back to my motherland and pursued my career and dream, not only as a musician but also as a music advocator and educator. I feel very grateful for this.

TZ: You have moved from a top musician/performer to a music educator. What makes you so dedicated in music education for the public?

KXD: For me, as a musician, performing music and teaching music are the same thing, and the stage is almost like a classroom. You can never separate yourself from being a performer and an educator. When performing on the stage, I always learn from my audiences, who become my teachers, and help me to be able to become a better musician. So, I don't really see that as a switch. By playing and teaching, it makes me be able to hear the feedback from the audience and improve my music creation and performance. I also enjoy being with children who I not only teach, but also communicate with by heart. Sometimes I am really moved by them, as they always tell the truth. Once I was asked by a little girl, "Professor Kong, why is there are so much music in the world?" The question really haunted me in my heart. The song of our heart is the thoughts of our soul. If we look inside to our hearts, the unique music of our soul will come to us eventually, and help us find the love for the whole of humankind.

TZ: With music, you meet people where they are. I really appreciate your dedication to public music education and getting people deeply connected with such a beautiful and essential thing in our life - music. It is a great mission. 
KXD: There are so many great musicians in this world in the past, present, and for sure, in the future, carrying on this mission: using music to help enrich our lives, to live better, understand life better, and make this world better. Let's go for this mission together.

TZ: What are the most challenging aspects for you in pubic music education? As Chinese education is very much skill and exam-oriented, how do you influence the society in that aspect?

KXD: With my 20 years' experience in music education in China, I found to make changes to the current skill and exam-oriented system is a very big task, and few people can do that alone. I try my very best to influence the society by talking with governmental officials, school principals, teachers, parents, and everyone I can reach. Eventually, I realized that I should not just be teaching people how to play music, but tell them how to enjoy the music instead. I would like to illustrate how we construct the Chinese character for "medicine" (薬) which is the combination of "music" (楽) and "herb" ${ }^{++}$), while actually, the Chinese character for "music" and "happiness" are exactly the same, conveying this philosophy. So, traditional Chinese believe in the healing power of music on people's illness and I believe music is medicine, but also something beyond medicine. I work with the children's hospitals to bring the music to the children patients there. The music not only comforts and supports their emotions, but also heals them beyond what medicine (alone) can do. Music can regulate people's moods and make us happy. The mood and temperature are two of the sources of illness. You have to be happy. If you are not happy, you will get sick easily. So, music can bring us happiness. When you pick up beautiful music, your mood switches - you feel better, more upbeat, more optimistic. That's why I encourage people to wake up to music - not just ringing bells. I use myself as an example in public education. Last month, I gave a public speech to some 500 people and shared with them my own experience of conquering depression, and how I healed myself with music. In the last seven months, I listened intensively to music in my daily life and I lost $27 \mathrm{~kg}$ of weight. Music can do wonders for our health; it's beyond all expectations. This music is not just for the fun of it, but as a cure. To help with anxiety, to get out of depression, to give us a better mood, and to bring more happiness.

TZ: So, you go beyond the traditional music education setting in school to do some work in the hospitals and the public. As a celebrity, usually it is a taboo in China to talk about one's own depression in public. What makes you so open to talk about it?

KXD: In the past, I had been very busy traveling all over China and doing lots of projects. However, I was not that happy, as I got stressed and depressed. I started to ask myself who I am and what I am going to do with my music and my mission. I spent 3 to 4 years to think about the goal of my life. I made a trip to Japan and spent nine days there visiting the temples and meditating. In one of the performances I gave there, I asked the audience to mask their eyes and listen to my piano playing. By disabling the visibility, I used the music to help all of us calm down and start to look inside of ourselves and our hearts. Thus, it is the healing power of music which enables me to share my personal experience, and I would like to do more such experiments and work in the future. 
TZ: China is developing very fast, and you live in Shanghai, one of the busiest cities in China. How do you look at the eagerness of Chinese people in the city for music/art? Do you see different patterns among different generations?

KXD: I see Chinese people have lots of pressure nowadays, especially the middle-aged Chinese who carry many responsibilities for work and the family. They need something beyond medicine, i.e., spiritual support. They need to be reminded of who they are, and be told they can do something they are looking for. On the other hand, all people like appreciate things like music. Good music could win the hearts of people of all ages. I feel privileged as a musician who can win people's hearts not only because of me, but also the beauty of the music itself. I am the servant of the music which makes meaning for my life. Thus, I like to bring music to different settings and people of all ages. After this interview, I will give a performance in the famous temple in Shanghai: Donghai Temple of Goddess of Mercy (see video 2). I will give an improvised performance on the site this weekend for visitors to the temple. The idea is to bring people back to the basics. I believe music and religion are the same, because music can spread a great message of kindness and well-being to the people, regardless of their ages and generations.

TZ: You have been very much influenced by Western music education. How does the ancient/traditional Chinese culture and philosophy influence you on a professional level and a personal level?

KXD: Indeed, I was born and lived in China until I was 19, and I had been in the US for ten years to study music. Before I was 30 years old, I had travelled to 40 countries and regions in the world, giving performances and attending competitions. However, I still feel Chinese deep in my heart, probably because of my family and blood of Confucius decedent. I was at different levels of understanding life. When I was young, I had lots of success of my career. But, then I felt it was not enough, and I wanted to go deeper to know the human relationship with the music. In the West, people study philosophy to understand who they are, and in the East, especially in China, we learn philosophy to understand the fates in our life. This curiosity has brought me to another way of understanding music in a philosophic way. Now I feel music is even deeper than philosophy, in a way that music is us, is you, me, and others. Everybody is a single source of music. With the modern digital and online technology, everyone can create music. I encourage people to embrace the new technology to create more possibilities and hope.

TZ: I am interested in the interface of tradition and the modern which sometimes have conflicts. China has the tradition of Three Teachings, which is the combination of Taoism, Confucianism and Buddhism. How do you reflect on your own identity as Chinese? What is your Confucian orientation in relation to the music?

KXD: You know, I am the first one in China to combine piano and temple, and also the first person to play Buddhist music on the piano. I never feel it was difficult blurring boundaries. Perhaps music is one of the easiest professions to erase the boundaries. 
Music is the common language. I try not to think of myself as only Chinese, but more as a human being. When I play music, I can reach every single heart. Music helps me overcome the limitations of religions and nationalities. The Master said, "I set my heart on the Way, base myself on virtue, lean up on benevolence for the support and take my recreation in the arts", (Confucian Analects, Chapter 7.6) . "Taking recreation in the arts" is the perfection realm in our traditional culture, which is also the art realm I will chasing in my life as the 75th descendant of Confucius.

TZ: You mentioned you play piano in the temple. How do you feel about it? And how do the public and the monks react to this special way of performing piano in the temple?

KXD: It is very special experience. The chief monk of the temple where I play is a singer, and probably the only monk in the country who can sing Buddhist music so well. In nearly every performance in the temple, people are so touched that they cry. I have been playing in so many concern halls in the world, but playing in the temple is very special for me. Somehow, I feel lifted and floating as I find more self-truth there. The music is not pre-composed, but all improvised. I want to share some temple music, playing videos with you, and let more people abroad know what Chinese musicians are doing now via CAET journal. I think education and performing in many different settings is important for musicians. I find myself not only a musician, but more a music advocate, nowadays. I like to bring the music to people and help improve their wellbeing. I would like to invite you and others to come to the improvisation performance in the Shanghai temple, and I am sure the chief monk will be more than delighted to receive you. 